\title{
ДОХОДЫ ФИЗИЧЕСКИХ ЛИЦ: ВОПРОСЫ НАЛОГООБЛОЖЕНИЯ ТРАНСГРАНИЧНЫХ ОПЕРАЦИЙ В РОССИЙСКОЙ ФЕДЕРАЦИИ
}

\begin{abstract}
О.А. Синенко
Проведено исследование налогообложения трансграничных операций физических лиц в России. Рассмотрены подходы к применению концепции лица, имеющего фактическое право на доход. Выделены особенности международных договоров РФ в сфере налогообложения. Систематизированы методы устранения двойного налогообложения. Сделан анализ налогообложении доходов физических лиц по налоговым ставкам, установленным в соглашениях об избежании двойного налогообложения за период 20112019 гг. Выделены особенности налогообложения определенных категорий доходов физических лиц, регулируемые в соглашениях об избежании двойного налогообложения РФ, а также рассмотрен порядок проведения взаимосогласительной процедуры разрешения споров по вопросам налогообложения.
\end{abstract}

Ключевые слова: НДФЛ, налог на доходы физических лиц, трансграничные операции, соглашения об избежании двойного налогообложения, фактический получатель дохода, устранение двойного налогообложения.

JEL-классификация: H20, H26, Н30.

DOI: $10.46782 / 1818-4510-2021-2-94-106$

Материал поступил 6.05.2021 2.

В 2020 г., по прогнозам Всемирного банка, трансграничные переводы будут испытывать негативное воздействие пандемии COVID-19. Как ожидается, совокупный объем трансграничных денежных переводов физических лиц, направленных в развивающиеся страны со средним и низким доходом, в 2020 г. снизится на 20\% до 445 млрд долл. СШАㄹ. Главной причиной станет снижение уровня оплаты иностранных работников в основных принимающих странах. По оценкам Всемирного банка, в наибольшей степени переводы сократятся в регионы Европы и Центральной Азии (на $27,5 \%$ ), Южной Азии (на $22,1 \%$ ) и Южной Африки (на 23,1\%)ㄹ.

1 Трансграничные переводы физических лиц в 2019 году. Банк России 2020. Москва. URL: https://www.cbr.ru/ Collection/Collection/File/29350/Cross-BorderOpsSurvey\% 202019.pdf

2 World Bank Predicts Sharpest Decline of Remittances in Recent History. 2020. URL: https://www.worldbank.org/ en/news/press-release/2020/04/22/world-bank-predictssharpest-decline-of-remittances-in-recent-history
Динамика трансграничных переводов из России за рубеж с 2006 по 2019 г., осуществленных физическими, лицами неоднозначна. В 2019 г. их объем сократился на $12,9 \%$ в результате снижения сумм перечислений в страны дальнего зарубежья на $16,7 \%$, в страны СНГ - на 2,9\%. Среди отправителей переводов преобладают резиденты (рис. 1).

В исходящем потоке трансграничных переводов основными странами назначения были: Швейцария, Узбекистан, Таджикистан, США, Соединенное Королевство и Киргизия. Совокупная доля отправлений в данные страны составила 47,5\% (19,8 млрд долл. США). Наибольший объем средств переведен в Узбекистан, Таджикистан и Швейцарию.

Крупнейшей страной - получателем денежных средств из России является Швейцария, что традиционно связано с размещением на банковских счетах в этой

* Синенко Ольга Андреевна (sinenko.oa@dvfu.ru), кандидат экономических наук, доцент, Дальневосточный Федеральный университет (г. Владивосток, Россия). 
Доходы физических лиц: вопросы налогообложения трансграничных операций...

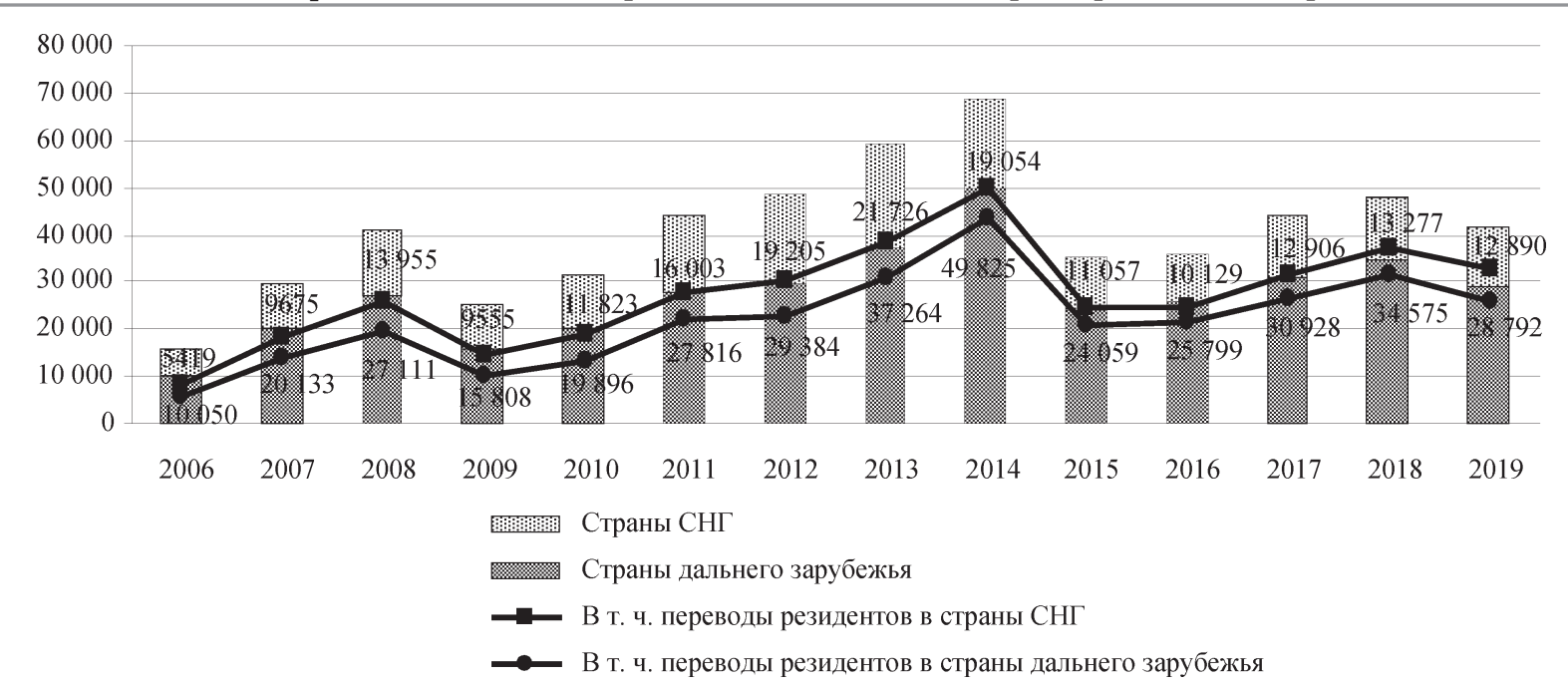

Рис.1. Трансграничные операции физических лиц - перечисления из России, 2006-2019 гг., млн долл. США

\begin{abstract}
Источник. Трансграничные переводы физических лиц (резидентов и нерезидентов). URL: https://cbr.ru/ statistics/macro_itm/tg/
\end{abstract}

юрисдикции собственных средств физическими лицами. Однако объем перечислений в 2019 г. в Швейцарию составил 5,8 млрд долл. США (13,9\% исходящего потока).

В целевой структуре переводов резидентов за рубеж доминировали перечисления средств на собственные счета в иностранных банках (14,2 млрд долл. США), хотя их доля в совокупном объеме перечислений физических лиц-резидентов снизилась до 43,0\%. Более половины средств было направлено в банки Швейцарии, Соединенного Королевства, США, Испании и Нидерландов. В 2019 г. зафиксировано снижение безвозмездных перечислений резидентами до 3,5 млрд долл. США. Их доля в исходящих переводах уменьшилась до 10,5\%, в структуре значительный объем операций пришелся на переводы в страны СНГ, в первую очередь в Армению, Узбекистан и Азербайджан. Суммарный стоимостной показатель переводов в счет оплаты товаров и услуг в исходящем потоке вырос в 2019 г. на 11,6\%. Лидирующие позиции среди переводополучателей за оказанные услуги занимали Швейцария, Соединенное Королевство, Кипр, США и Италия.

Объем переводов в пользу физических лиц в РФ в 2019 г. составил 25,1 млрд долл. США. Как и в предыдущие годы, преобладающая часть средств (22,5 млрд долл. США, или $89,7 \%$ входящего потока) поступила в пользу резидентов $Ф^{3}$. В России наблюдается отрицательное сальдо по трансграничным переводам физических лиц. Усложнение трансграничных операций и необходимость усиления контроля со стороны контролирующих органов создают новые вызовы как для налоговых органов, так и для налогоплательщиков. Адаптация к правилам подоходного налогообложения трансграничных операций становится одним из аспектов успешного развития бизнеса.

\section{Подходы к применению концепиии лица, имеющего фактическое право на доход}

Применять льготный порядок налогообложения доходов физических лиц от трансграничных операций возможно лишь к доходам фактического получателя. В случае выплаты доходов не фактическому получателю, а номинальному посреднику (кондуиту), к подобной сделке не применяются положения международного соглашения со страной, резидентом которой является посредник, и действуют общие правила налогообложения. Применение международных налоговых соглашений исключительно для получения льгот ФНС

3 Трансграничные переводы физических лиц в 2019 году. URL: https://www.cbr.ru/Collection/Collection/File/ 29350/Cross-BorderOpsSurvey\%202019.pdf 
признает неправомерным4. Для обоснования применения налоговых льгот по международным соглашениям налогоплательщик в соответствии с п. 1. ст. 312 НК РФ обязан самостоятельно подтвердить факт того, что является фактическим получателем дохода ${ }^{5}$.

В соответствии с п. 2 ст. 7 НК РФ фактическим получателем дохода признается лицо (иностранная структура без образования юридического лица), если имеет право самостоятельно пользоваться и/или распоряжаться полученным доходом в силу прямого или косвенного участия, контроля над организацией (иностранной структурой) либо в силу иных обстоятельств ${ }^{6}$. При этом фактическое право на доходы определяется по каждой отдельной выплате в виде дивидендов и/или по группе выплат в рамках одного договора (п. 2 ст. 7 НК РФ).

Лицо признается фактическим получателем дохода, если является непосредственным выгодоприобретателем, т. е. фактически получает выгоду от полученного дохода и определяет его дальнейшую экономическую судьбу ${ }^{7}$. В соответствии с письмом ФНС РФ, для подтверждения фактического получателя дохода налогоплательщики должны обосновать ${ }^{8}$ :

необходимость определенной формы совершения сделок;

цель вовлечения иностранных компаний в структуру бизнеса и сделок;

разумность сделанного выбора и наличие предпринимательского риска.

При этом законодательно не установлен перечень документов, подтверждающих статус фактического получателя дохода, что сви-

${ }^{4}$ Письмо ФНС России от 28.04.2018 г. № СА-4-9/ 8285 «О практике рассмотрения споров по применению концепции лица, имеющего фактическое право на доход (бенефициарного собственника)».

5 Налоговый кодекс Российской Федерации (часть первая) от 31.07.1998 г. № 146-Ф3 (ред. от 23.11.2020 г.).

URL: http://www.consultant.ru/document/cons_doc_ LAW_327521/17d01b2574b70fa72397256221039ccf439d4981/

${ }^{6}$ Там же.

7 Письмо ФНС России от 21.01.2020 г. № БС-4-11/ 882@ «О налогообложении доходов физических лиц» (вместе с Письмом Минфина России от 20.01.2020 г. № 03-04$07 / 2404)$

8 Письмо ФНС России от 28.04.2018 г. № СА-4-9/ $8285 \ll О$ практике рассмотрения споров по применению концепции лица, имеющего фактическое право на доход (бенефициарного собственника)». детельствует об отсутствии ограничений для налоговых агентов и предпочтении содержательной части полученной информации для ФНС РФ. Физические лица или организации по доходам, которые получены с 01.01.2018 г., применяют упрощенный порядок подтверждения фактического получателя дохода, для применения которого достаточно представить (п. 1.5 ст. 312 НК РФ):

письмо-подтверждение о наличии фактического права на доход;

документы, подтверждающие установленные критерии.

В то же время упрощенный порядок подтверждения фактического получателя дохода не отменяет требования о том, что лицо, имеющее фактическое право на доход в виде дивидендов, должно прямо и/или косвенно участвовать в российской организации, выплатившей данный доход 9 .

Для установления фактического получателя дохода и исключения претензии налоговых органов о техническом характере участия иностранной компании осуществляется оценка роли и деловой цели иностранного лица в конкретной сделке. При оценке доказательств осуществления деятельности иностранной компанией учитываются такие критерии, как реальная хозяйственная деятельность и реальное присутствие. ФНС России в рамках контрольных мероприятий рекомендует осуществлять анализ на наличие признаков искусственности в деятельности компании ${ }^{10}$. При этом налоговый орган учитывает в качестве доказательств ведения самостоятельной предпринимательской деятельности иностранной компанией следующее:

наличие источников дохода, кроме дивидендов, процентов по займам взаимозависимым и аффилированным лицам;

долю доходов, полученных по другим направлениям;

${ }^{9}$ Письмо Минфина России от 01.04.2019 г. № 03-0805/22411 «О налоге на прибыль при выплате дивидендов иностранной организации, указавшей, что фактическим получателем дохода является государственный суверенный фонд».

${ }^{10}$ Письмо ФНС России от 08.08.2019 г. № ЕД-4-13/ $15696 @ \ll$ фактическом праве холдинговых компаний на доход от источников в Российской Федерации». URL: https://www.nalog.ru/rn77/about_fts/about_nalog/8976163/ 
Доходы физических лиц: вопросы налогообложения трансграничных операций...

основную цель деятельности, которая не должна заключаться в выведении доходов из-под налогообложения в РФ.

В обзоре судебных споров по вопросам применения положений международных налоговых договоров и злоупотребления законодательством при трансграничных операциях ФНС разъясняет применение законодательства в рамках установления бенефициарного собственника и злоупотреблений при осуществлении хозяйственных операций с иностранными контрагентами ${ }^{11}$. Правильность определения фактического получателя дохода устанавливается в зависимости от ситуации. Например, по операциям с дивидендами подтверждением может являться схема цепочки владения долями в капиталах компаний. Факт получения реального, а не «транзитного», дохода может быть подтвержден включением в финансовый результат и в налоговую базу иностранной компании.

\section{Международные договоры в сфере налогообложения}

В соответствии с п. 1 ст. 7 Налогового кодекса РФ ${ }^{12}$ правила международных договоров РФ имеют приоритет перед российским налоговым законодательством. Международные договоры в сфере налогообложения регулируют вопросы предотвращения уклонения от уплаты налогов на доходы и имущество, избежания двойного налогообложения, защиты капиталовложений и инвес-

11 Письмо Федеральной налоговой службы от 06.05.2019 г. № СА-4-7/8448@ «Обзор судебных споров по вопросам применения положений международных налоговых договоров и злоупотребления законодательством при трансграничных операциях». URL: https://www.garant.ru/products/ ipo/prime/doc/72149880/

12 Налоговый кодекс Российской Федерации (часть первая) от 31.07.1998 г. № 146-Ф3 (ред. от 09.11.2020г.). URL: http://www.kremlin.ru/acts/bank/12755 тиций, а также вопросы сотрудничества по торговым и административным делам (рис. 2).

Правительство РФ по состоянию на 2020 г. подписало с правительствами 83 иностранных государств и Правительством Специального административного района Гонконг КНР ${ }^{13}$ соглашения об избежании двойного налогообложения и о предотвращении уклонения от уплаты налогов на доходы и имущество, где содержатся условия по применению льготных процентных ставок или освобождению от уплаты налога на территории источника дохода. Сферу налогообложения затрагивают также международные договоры РФ о поощрении и взаимной защите капиталовложений и инвестиций, заключенные РФ с 81 страной и с государствами ЕАЭС. C 01.04.2020 г. международные договоры РФ применяются к отношениям, регулируемым законом № 69-Ф3 ${ }^{14}$. Кроме того, РФ заключены международные договоры о сотрудничестве и взаимной помощи в таможенных делах с 64 странами, а также с членами Таможенного союза в рамках ЕАЭС, членами ЕС и государствами - членами Шанхайской организации сотрудничества, а также международные договоры о сотрудничестве и правовой помощи по гражданским, торговым, трудовым и административным делам.

13 Соглашение между Правительством Российской Федерации и Правительством Специального административного района Гонконг Китайской Народной Республики об избежании двойного налогообложения и предотвращении уклонения от налогообложения в отношении налогов на доходы. URL: https://docs.cntd.ru/document/420336687

14 URL: http://www.kremlin.ru/acts/bank/45357; Постановление Правительства РФ № 1577 от 01.10.2020 г. «О Правилах заключения, изменения, прекращения действия соглашений о защите и поощрении капиталовложений, ведения реестра соглашений о защите и поощрении капиталовложений».

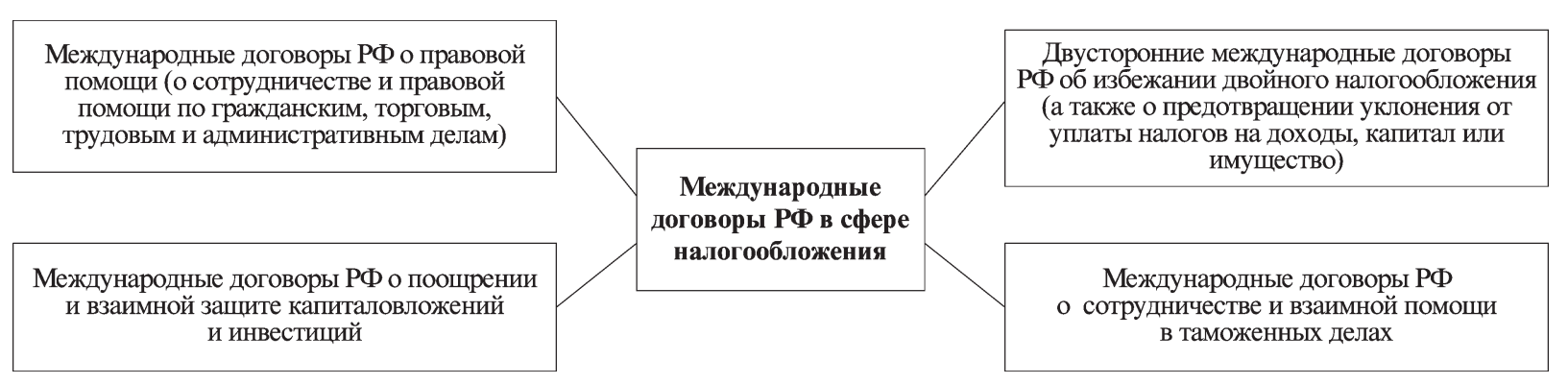

Рис. 2. Международные договоры РФ в сфере налогообложения, 2020 г.

Источник. Авторская разработка. 
Первые двусторонние налоговые соглашения в мировой практике были заключены Бельгией: с Францией (1843 г.), Нидерландами (1845 г.), Люксембургом (1845 г.) (Jogarajan, 2012). В 1872 г. Великобритания и Швейцария (Кантон Во (Vaud)) подписали первый Договор об избежании двойного налогообложения, который распространялся на налог на наследство. Инициатором заключения договора выступила Великобритания с целью разрешения разногласий между юрисдикциями, которые возникали после смерти многих известных и состоятельных подданных Великобритании, проживающих в отличающемся теплым климатом Кантоне Во. Как отмечается, международное двойное налогообложение возникает в результате конфликтов между национальными законодательствами двух стран (Holmes, 2007):

конфликт источников - согласно национальному законодательству стран, доход или капитал получены на их территории (в пределах их границ);

конфликт резидентства - обе страны рассматривают лицо как своего налогового резидента (двойное резидентство); конфликт источника и резидентства обе страны облагают налогом тот же доход или капитал, при этом налогоплательщик является жителем одной страны, а доход или капитал получены из источника в пределах другой страны.

Таким образом, в договорах об избежании двойного налогообложения доходы (капитал) классифицируются по трем видам в зависимости от режима, применимого к каждому виду в государстве источника дохода ${ }^{15}$ (Синенко, 2016):

доходы подлежат налогообложению в государстве источника дохода без ограничений;

доходы подлежат ограниченному налогообложению в государстве источника дохода;

доходы не могут подлежать налогообложению в государстве источника дохода.

В случае если доход или капитал облагается налогом с ограничением (или без

15 Синенко О.А. 2016. Налогообложение физических лии: учебное пособие. Владивосток: Дальневосточный федеральный университет. ограничения) в государстве источника дохода или местонахождения, то государство резидентства устраняет двойное налогообложение. Устранение двойного налогообложения осуществляется одним из двух методов: освобождением либо зачетом. Основная разница между методами заключается в том, что при методе освобождения ключевую роль играет доход, а при методе зачета - налог (рис. 3)

В Российской Федерации применяется только метод зачета, при этом сумма вычета не должна превышать сумму налога на доход, рассчитанного до предоставления вычета, относящегося к доходу, который может подлежать налогообложению в другом государстве ${ }^{16}$.

Структура международного договора об избежании двойного налогообложения может быть представлена следующим образом:

сфера действия (лица и налоги);

термины и правила толкования;

основа каждого договора - правила распределения налоговых юрисдикций по видам доходов (дистрибутивные правила); методы устранения двойного налогообложения;

специальные положения (о недискриминации, обмене информацией, содействии государств друг другу в сборе налогов, налоговых режимах дипломатических агентов и консульских служащих и т. д.);

заключительные положения (вступление в силу, прекращение действия) (Хаванова, 2016).

\section{Устранение двойного налогообложения доходов физических лич, в РФ}

Первый договор об избежании двойного налогообложения появился еще в СССР в 1985 г. (с Великобританией) и содержал в себе процедуры взаимного соглашения при урегулировании спорных вопросов. Уже тогда страны стремились решить спорный вопрос по взаимному согласию с целью избежать двойного налогообложения и спорных ситуаций (Князев, 2019). С 01.10.2019 г. в

16 Постановление Правительства РФ от 24.02.2010 № $84 \ll \mathrm{O}$ заключении межгосударственных соглашений об избежании двойного налогообложения и о предотвращении уклонения от уплаты налогов на доходы и имущество» (ред. от 26.04.2014 г.). 
Доходы физических лиц: вопросы налогообложения трансграничных операций...

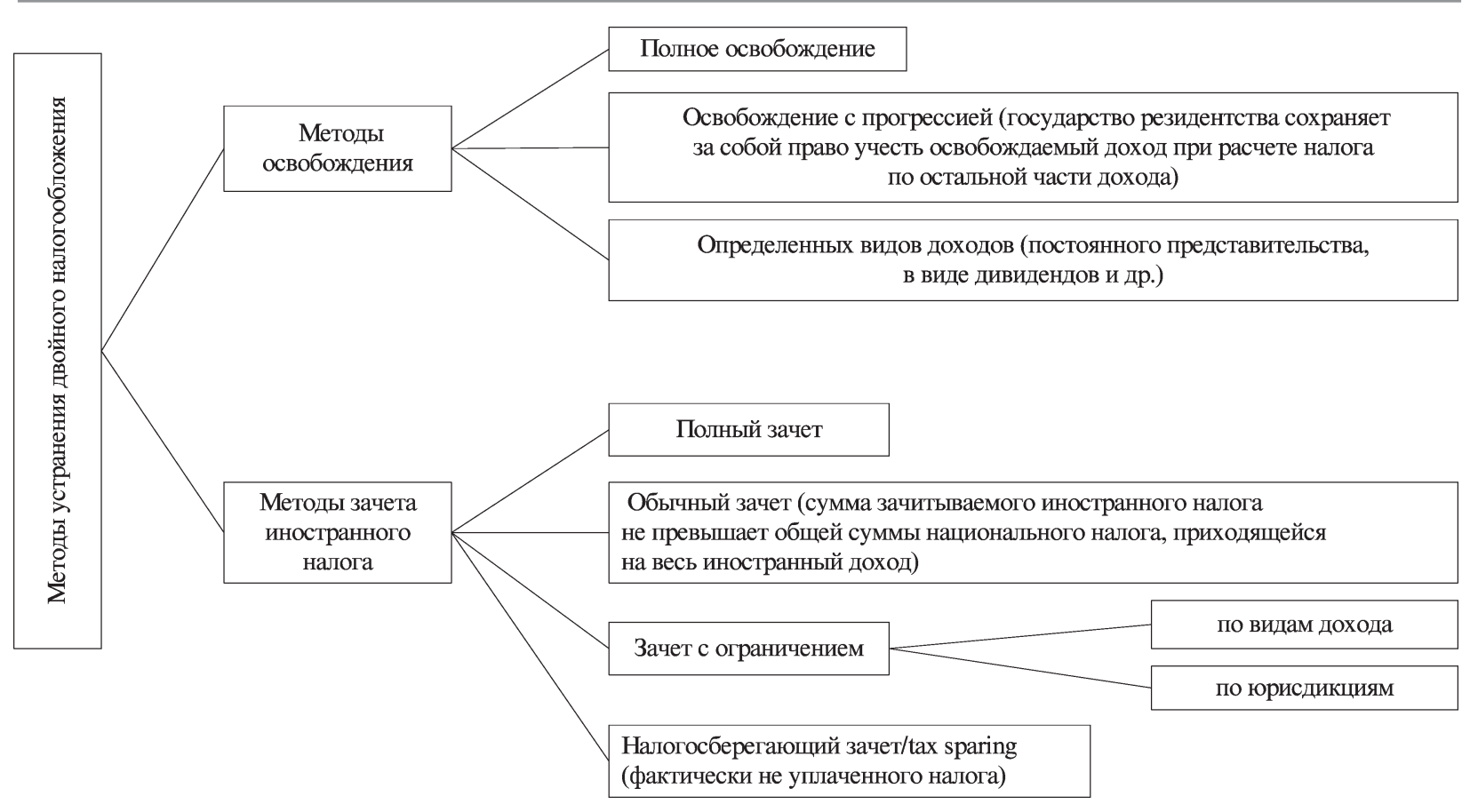

Рис. 3. Методы устранения двойного налогообложения

Источник. Типовая конвенция Организации Объединенных Наций об избежании двойного налогообложения в отношениях между развитыми и развивающимися странами. 2011. URL: https://www.un.org/esa/ffd/wpcontent/uploads/2014/09/UN_Model_2011_UpdateRu.pdf

РФ вступила в силу многосторонняя Конвенция по выполнению мер, относящихся к налоговым соглашениям, в целях противодействия размыванию налоговой базы и выводу прибыли из-под налогообложения (MLI BEPS) от 24.11.2016 г. ${ }^{17}$ Нормы многосторонней Конвенции применяются в отношении российских соглашений об избежании двойного налогообложения, на которые она распространяется с 01.01.2021 г. Соглашения об избежании двойного налогообложения применяются с учетом положений многосторонней конвенции по противодействию размыванию налоговой базы и требований налогового законодательства РФ в отношении фактического получателя дохода (ФПД). В соответствии с п. 2. ст. 7 НК РФ фактическим получателем дохода признается лицо, которое имеет право самостоятельно пользоваться и (или) распоряжаться доходом, полученным другой организацией (в силу прямого участия, косвен-

17 Федеральный закон от 01.05.2019 г. № 79-ФЗ «О ратификации многосторонней Конвенции по выполнению мер, относящихся к налоговым соглашениям, в целях противодействия размыванию налоговой базы и выводу прибыли из под налогообложения». URL: http://www.kremlin.ru/acts/bank/ 44248 ного участия, контроля над организацией или иных обстоятельств), или иное лицо, которое правомочно распоряжаться полученным доходом. Обладание фактическим правом на дивиденды, проценты и роялти является обязательным условием применения соглашений ${ }^{18}$. При этом в рамках действующих соглашений нашли отражение разные подходы к определению понятия «Фактический получатель дохода» (табл. 1).

Таким образом, лицо признается фактическим получателем дохода - непосредственным выгодоприобретателем - при наличии правовых оснований для этого и при приобретении выгоды от дохода и определении его дальнейшей экономической судьбы ${ }^{19}$.

Соглашения об избежании двойного налогообложения, заключенные РФ, определяют:

${ }^{18}$ Постановление Правительства РФ от 24.02.2010 г. № $84 \ll О$ заключении межгосударственных соглашений об избежании двойного налогообложения и о предотвращении уклонения от уплаты налогов на доходы и имущество» (ред. от 26.04.2014 г.).

${ }_{19}$ Письмо Министерства Финансов РФ № 03-12-12/ 2/60389 от 24 августа 2018 г. «О признании лица фактическим получателем дохода в целях налогообложения» 
Таблица 1

Подходы к определению понятия «непосредственный выгодоприобретатель», применяемые в соглашениях об избежании двойного налогообложения РФ

\begin{tabular}{|l|l|}
\hline \multicolumn{1}{|c|}{ Определение } & \multicolumn{1}{|c|}{ Государство - партнер по соглашению } \\
\hline $\begin{array}{l}\text { Имеет фактическое право на доход /фактически } \\
\text { имеет право на доход }\end{array}$ & $\begin{array}{l}\text { Австралия, США, Канада, Нидерланды, Япония, } \\
\text { Великобритания, Бельгия, Бразилия, Новая Зеландия }\end{array}$ \\
\hline Фактический владелец дохода & Алжир, Нидерланды \\
\hline $\begin{array}{l}\text { Обладатель права собственности на доход / лицо, } \\
\text { фактически обладающее правом собственности } \\
\text { на доход }\end{array}$ & Армения, Дания, Германия, Мальта \\
\hline Фактический получатель дохода & Франция, Вьетнам \\
\hline
\end{tabular}

Источник. Данные межгосударственных соглашений об избежании двойного налогообложения.

порядок признания организаций и физических лиц резидентами той или иной страны;

перечень налогов, для которых их применяют (в российском законодательстве порядок устранения двойного налогообложения установлен в отношении налога на прибыль организаций, налога на имущество организаций и налога на доходы физических лиц);

правила зачета (вычета) налога, уплаченного в одной стране, в счет налога в другой стране;

правила обложения конкретных видов доходов или имущества (в каком государстве, по какой ставке и т. д.).

В соответствии с формой типового соглашения между Российской Федерацией об избежании двойного налогообложения и о предотвращении уклонения от уплаты налогов на доходы и в рамках действующих международных договоров РФ в табл. 2 выделены общие особенности порядка налогообложения для определенных видов доходов.

По общему правилу, в соответствии с п. 1. ст. 232 НК РФ, физические лица налоговые резиденты РФ не могут зачесть налог с доходов, полученный в иностранном государстве, в счет налога на доходы физических лиц в РФ. Зачет возможен, только если данная процедура предусмотрена международным соглашением РФ с государством, в котором налог с дохода был уплачен (Синенко, 2020).

С 2020 г. налогоплательщики, перешедшие на уплату НДФЛ с фиксированной прибыли, отказываются от уменьшения суммы налога, исчисленного с фиксированной прибыли, на суммы налога, уплаченные физическим лицом - налоговым резидентом РФ в иностранном государстве с полученных им доходов. Факт представления в налоговый орган уведомления о переходе на уплату налога на доходы физических лиц с фиксированной прибыли является основанием для такого отказа ${ }^{20}$.

Зачет в РФ суммы НДФЛ, уплаченной налоговым резидентом РФ в иностранном государстве с полученных им доходов, производится на основании представленной налоговой декларации, в которой указывается подлежащая зачету сумма налога, уплаченная в иностранном государстве. К налоговой декларации прилагаются подтверждающие документы и их нотариально заверенный перевод на русский язык:

- документы, подтверждающие суммы полученного дохода и уплаченного налога в иностранном государстве, выданные уполномоченным органом этого государства;

- копия налоговой декларации, представленной в иностранном государстве;

- документы, выданные налоговым агентом в иностранном государстве, подтверждающие сведения о суммах дохода в разрезе каждого месяца, а также о суммах налога, удержанных у источника выплаты дохода в иностранном государстве.

При этом налогоплательщик имеет право заявить о зачете в течение трех лет пос-

20 Федеральный закон от 09.11.2020 г. № 368-ФЗ «О внесении изменений в части первую и вторую Налогового кодекса Российской Федерации». 
Особенности налогообложения определенных категорий доходов физических лиц, регулируемые в соглашениях об избежании двойного налогообложения РФ

\begin{tabular}{|c|c|}
\hline $\begin{array}{c}\text { Категории доходов } \\
\text { физических лиц }\end{array}$ & Типовой порядок налогообложения \\
\hline Доходы от работы по найму & $\begin{array}{l}\text { Подлежат налогообложению в государстве, где расположен источник дохода, } \\
\text { за исключением случаев, когда: } \\
\text { получатель находится в другом государстве не более } 183 \text { дней в течение } \\
\text { любого двенадцатимесячного периода; } \\
\text { вознаграждение выплачивается нанимателем или от имени нанимателя, } \\
\text { не являющегося лицом с постоянным местопребыванием в другом } \\
\text { договаривающемся государстве; } \\
\text { расходы по выплате вознаграждения не несет постоянное представительство } \\
\text { или постоянная база, которые наниматель имеет в другом государстве }\end{array}$ \\
\hline $\begin{array}{l}\text { Доход от оказания } \\
\text { профессиональных услуг } \\
\text { или другой деятельности } \\
\text { независимого характера }\end{array}$ & $\begin{array}{l}\text { Облагается в государстве, в котором получен доход, за исключением } \\
\text { случаев, когда регулярно доступная постоянная база для целей } \\
\text { осуществления деятельности располагается в другом государстве }\end{array}$ \\
\hline Гонорары директоров & Могут облагаться налогами в другом государстве \\
\hline $\begin{array}{l}\text { Доходы артистов } \\
\text { и спортсменов }\end{array}$ & $\begin{array}{l}\text { Облагаются налогом в государстве, в котором осуществляется } \\
\text { их деятельность }\end{array}$ \\
\hline $\begin{array}{l}\text { Пенсии, другое подобное } \\
\text { вознаграждение в связи } \\
\text { с прошлой работой по найму } \\
\text { и аннуитеты }\end{array}$ & Подлежат налогообложению только в государстве резидента \\
\hline $\begin{array}{l}\text { Доходы от прохождения } \\
\text { государственной службы }\end{array}$ & $\begin{array}{l}\text { Вознаграждения и пенсии в отношении службы подлежат налогообложению } \\
\text { только в государстве, которое выплачивает данный доход, исключение: } \\
\text { вознаграждение подлежит налогообложению в другом государстве, если } \\
\text { служба осуществляется в этом государстве и физическое лицо имеет в нем } \\
\text { постоянное место жительства (например, является гражданином) }\end{array}$ \\
\hline $\begin{array}{l}\text { Доходы студентов } \\
\text { и стажеров }\end{array}$ & $\begin{array}{l}\text { Не облагаются налогом в государстве, в котором получается образование } \\
\text { или проходит практика при условии, что такие выплаты поступают } \\
\text { из источников в другом государстве }\end{array}$ \\
\hline $\begin{array}{l}\text { Доходы от авторских прав } \\
\text { и лицензий }\end{array}$ & $\begin{array}{l}\text { Доходы, возникающие в одном государстве и выплачиваемые лицу } \\
\text { с постоянным местопребыванием в другом государстве, подлежат } \\
\text { налогообложению в государстве пребывания получателя, если он имеет } \\
\text { фактическое право на такие доходы, при этом по соглашению сторон могут } \\
\text { облагаться налогом в этом другом государстве }\end{array}$ \\
\hline $\begin{array}{l}\text { Доходы от отчуждения } \\
\text { имущества }\end{array}$ & $\begin{array}{l}\text { Доходы или прибыль, полученные резидентом одного государства от } \\
\text { отчуждения недвижимого имушества, находящегося в другом государстве, } \\
\text { могут облагаться налогом в другом государстве }\end{array}$ \\
\hline Процентные доходы & $\begin{array}{l}\text { Проценты, возникающие в одном государстве, фактическое право на которые } \\
\text { имеет резидент другого государства, могут облагаться налогом в этом } \\
\text { другом государстве. При этом в ряде соглашений предусмотрены } \\
\text { дополнительные условия. Например, проценты могут также облагаться } \\
\text { налогом в государстве, в котором они возникают, но взимаемый таким } \\
\text { образом налог не должен превышать } 10-15 \% \text { от общей суммы процентов }\end{array}$ \\
\hline
\end{tabular}

Источник. Данные НК РФ.

ле окончания налогового периода, в котором были получены данные доходы.

Налоговые агенты РФ не учитывают суммы налога на доходы, уплаченные физическим лицом - резидентом РФ в иностранном государстве, при расчете и удер- жании НДФЛ. В России доходы налоговых резидентов иностранных государств облагаются только от источников в РФ. Если в рамках международного договора отдельные доходы резидента иностранного государства освобождаются от НДФЛ в 
России, то налоговый агент РФ по данным доходам (п. п. 5, 6, 7 ст. 232 НК РФ):

не удерживает НДФЛ или удерживает налог в меньшем размере - при наличии подтверждения резидентства физического лица до выплаты дохода;

возвращает излишне удержанный НДФЛ нерезиденту, если документы получены резидентом после выплаты дохода и удержания налога.

Таким образом, международные договоры в сфере подоходного налогообложения граждан поддерживают стремление решать по взаимному согласию любые трудности или вопросы, возникающие при толковании или применении действующего законодательства и международных норм и правил. Данный механизм направлен прежде всего на защиту интересов налогоплательщика и позволяет не только установить прозрачные правила налогообложения, но и решить часть спорных и сложных ситуаций.

\section{Взаимосогласительная процедура разрешения споров по вопросам налогообложения}

В 2020 г. с целью разрешения споров по вопросам налогообложения раздел VII. 1 HК РФ был дополнен главой 20.3, посвященной взаимосогласительной процедуре в рамках международных договоров РФ. Если налогоплательщик считает, что положения международного соглашения применены некорректно, он может обратиться в компетентные органы любой страны в соответствии с соглашением. Взаимосогласительная процедура разрешения споров в соответствии со ст. 142.7 НК РФ применяется к порядку налогообложения доходов, прибыли и имущества лица в рамках положений международных договоров РФ по вопросам налогообложения. Инициировать процедуру может налогоплательщик или компетентный орган иностранного государства, являющегося соответствующей стороной международного договора. По результатам взаимосогласительной процедуры не осуществляются корректировки регистров налогового учета и первичных документов, при этом корректировки отражаются в налоговых декларациях по налогам (по налогу на прибыль организаций и НДФЛ). Если в связи с проведенными корректировками налогоплательщик получает право на зачет или возврат суммы налога, то указанная сумма налога подлежит зачету или возврату в порядке, установленном ст. 78 НК РФ.

Порядок проведения взаимосогласительной процедуры определяется положениями соответствующего международного договора $^{21}$. Заявление может быть представлено налогоплательщиком в срок до истечения трех лет со дня вручения акта налоговой проверки, мотивированного мнения налогового органа в рамках налогового мониторинга, а также акта, составленного по решению налогового органа иностранного государства, являющегося стороной применимого международного договора. В течение 90 дней с даты получения заявления Минфин России по результатам рассмотрения документов и их проверки на соответствие установленным требованиям принимает решение о проведении взаимосогласительной процедуры или решение о мотивированном отказе в ее проведении. По результатам взаимосогласительной процедуры могут быть определены следующие моменты:

- срок подачи заявления о зачете или о возврате суммы излишне уплаченного или взысканного налога;

- порядок учета доходов (прибыли, выручки) в рамках контроля за трансфертным ценообразованием;

- применение для целей налогообложения минимального или максимального значения интервала рыночных цен в рамках контроля за трансфертным ценообразованием.

\section{Порядок налогообложения доходов физических лич, от трансграничных операций}

Вопросы налоговых последствий совершения трансграничных операций неизбежно затрагивают раздел международного налогообложения. Вариативность соверше-

${ }^{21}$ Приказ Минфина России от 11 июня 2020 г. № 102н «Об утверждении Порядка и сроков представления и рассмотрения заявления о проведении взаимосогласительной процедуры в соответствии с международным договором Российской Федерации по вопросам налогообложения». URL: https://www.garant.ru/products/ipo/prime/doc/74526658/ 
Доходы физических лиц: вопросы налогообложения трансграничных операций...

ния трансграничных сделок и комбинация национального законодательства с международными договорами об избежании двойного налогообложения предполагают особый порядок налогообложения данных операций. При выплате доходов необходимо учитывать конечного бенефициара. Если доход получает иностранное лицо, которое не является фактическим получателем, то доходы признаются выплаченными лицу, имеющему фактическое право на них (п. 4 ст. 7 НК РФ). В случае, если фактический получатель неизвестен, может быть раскрыта вся цепочка получения дохода вплоть до конечного бенефициара в соответствии с принципом прозрачности. При выплате доходов конечному бенефициару - фактическому получателю возможно применение налоговых льгот в рамках международных соглашений при условии документального подтверждения. Порядок налогообложения доходов физических лиц в России от трансграничных операций зависит от статуса фактического получателя дохода (рис. 4).

При выплате доходов от источников в РФ иностранному лицу (иностранной структуре без образования юридического лица), не имеющему фактического права на такие доходы, российской организацией, выплачивающей данные доходы, не удерживается налог с иностранного лица. Если источнику выплаты известно лицо, которое имеет фактическое право на такие доходы и признается налоговым резидентом РФ, то налогообложение выплачиваемого дохода (его части) производится в соответствии с положениями главы 23 НК РФ ${ }^{22}$. Таким образом, российская организация выступает налоговым агентом в отношении дохода, получаемого российским резидентом - фактическим получателем ${ }^{23}$.

В случае, если фактический получатель дохода является нерезидентом РФ, то порядок налогообложения зависит от наличия или отсутствия заключенного международного соглашения об избежании двойного налогообложения со страной резиденства получателя дохода. При отсутствии международного соглашения источник дохода обязан выполнять функции налогового агента в общем порядке налогообложения доходов нерезидентов РФ (пп. 3, п. 4, ст. 7 НК РФ).

Налогообложение доходов нерезидентов при наличии со страной резидентства международного соглашения осуществляется на основе положений международного соглашения с той страной, резидентом которой является фактический получатель дохода (пп. 2 п. 4 ст. 7 НК РФ). Кроме того, необходимо учитывать наличие дохода от участия в деятельности иностранной компании (посредника) у фактического получателя дохода и факт декларирования и уплаты налогов с таких доходов. Анало-

${ }^{22}$ Налоговый кодекс Российской Федерации (часть вторая) от 05.08.2000 г. № 117-Ф3 (ред. от 29.12.2020 г.). URL: http://base.garant.ru/10900200/

${ }^{23}$ Письмо ФНС России от 21.01.2020 г. № БС-4-11/ $882 @$ «О налогообложении доходов физических лиц» (вместе с Письмом Минфина России от 20.01.2020 г. № 03-04$07 / 2404)$.

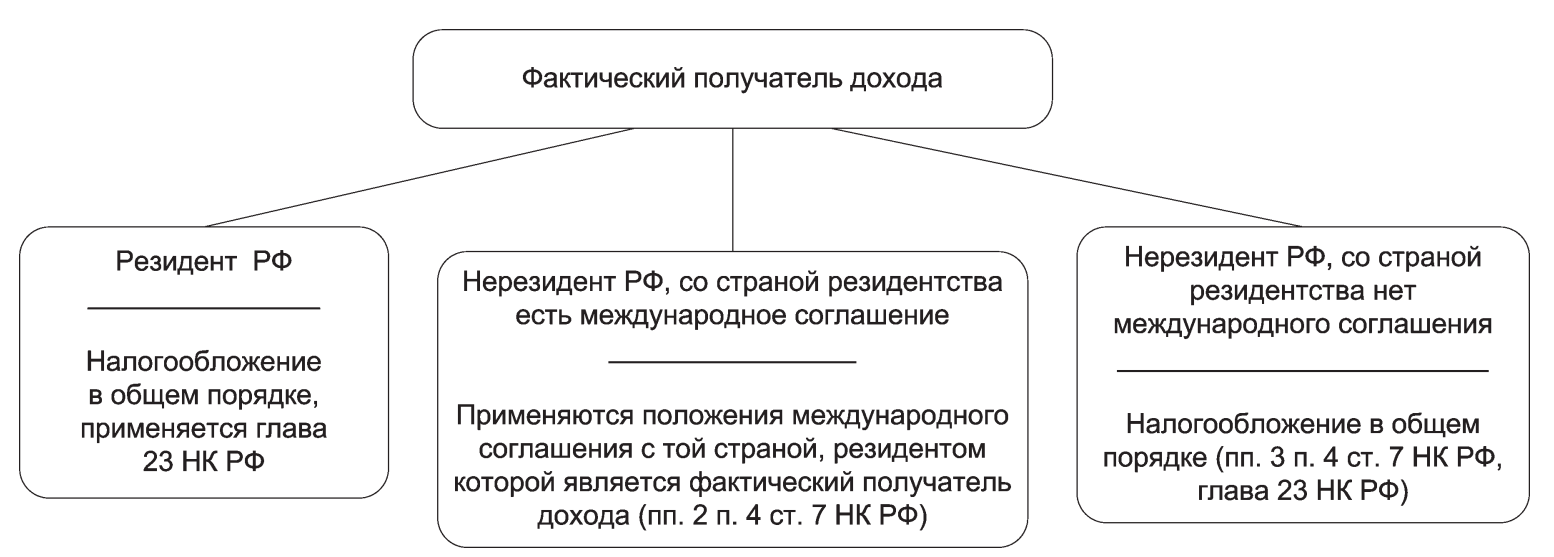

Рис. 4. Налогообложение доходов физических лиц от трансграничных операций в зависимости от статуса фактического получателя дохода

Источник. Данные НК РФ (часть первая). 
гичный порядок применяется и в отношении налогообложения доходов в виде дивидендов (п. 1.1 ст. 312 НК РФ). Налоговая база в отношении подобных выплат определяется как сумма выплачиваемых дивидендов. К ней применяется ставка 15\%, установленная п. 3 ст. 224 НК РФ (для физических лиц - нерезидентов). Особен- ности исчисления и уплаты налога с доходов в виде дивидендов в пользу иностранных лиц установлены ст. 312 НК РФ.

Анализ данных о налогообложении доходов физических лиц по налоговым ставкам, установленным в соглашениях об избежании двойного налогообложения в РФ за 2011-2019 гг. (табл. 3, рис. 5), свидетель-

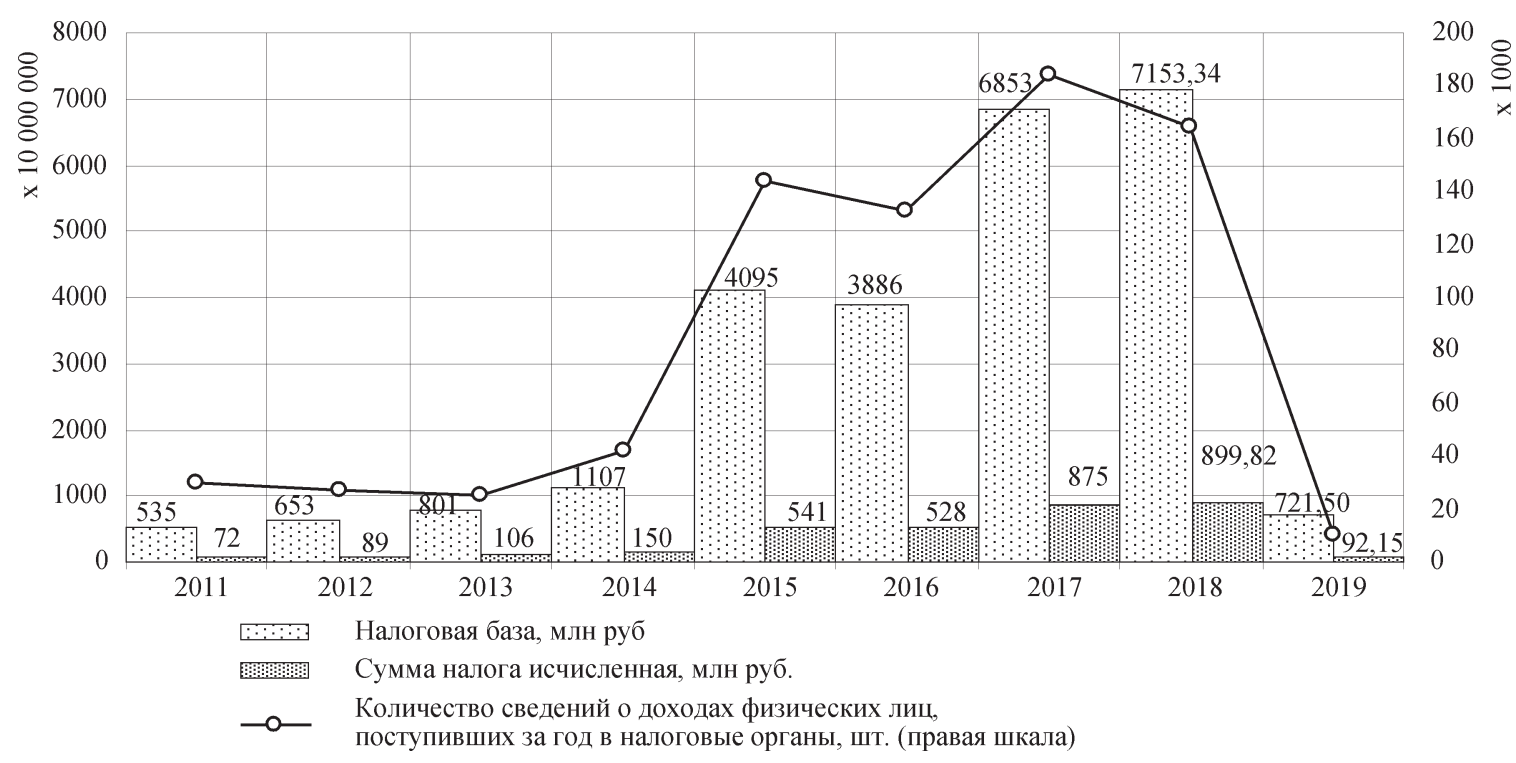

Рис. 5. Сведения о налогообложении доходов физических лиц по налоговым ставкам, установленным в соглашениях об избежании двойного налогообложения, 2011-2019 гг.

Источник. URL: https://www.nalog.ru/rn77/related_activities/statistics_and_analytics/forms/

Таблица 3

Сведения о налогообложении доходов физических лиц по налоговым ставкам, установленным в соглашениях об избежании двойного налогообложения, 2011-2019 гг.

\begin{tabular}{|l|c|c|c|c|c|c|c|c|c|}
\hline \multicolumn{1}{|c|}{ Показатель } & 2011 & 2012 & 2013 & 2014 & 2015 & 2016 & 2017 & 2018 & 2019 \\
\hline $\begin{array}{l}\text { Количество сведений } \\
\text { о доходах физических лиц, } \\
\text { поступивших за год } \\
\text { в налоговые органы, шт. }\end{array}$ & 30312 & 26920 & 25050 & 41629 & 144227 & 133110 & 184350 & 164139 & 10115 \\
\hline $\begin{array}{l}\text { Общая сумма дохода, } \\
\text { млн руб. }\end{array}$ & 5618 & 6691 & 8051 & 11586 & 42740 & 39480 & 72005 & 71589 & 7219 \\
\hline $\begin{array}{l}\text { Налоговая база по НДФЛ, } \\
\text { млн руб. }\end{array}$ & 5349 & 6532 & 8014 & 11073 & 40951 & 38858 & 68533 & 71533 & 7215 \\
\hline $\begin{array}{l}\text { Сумма НДФЛ } \\
\text { исчисленная, млн руб. }\end{array}$ & 718 & 885 & 1056 & 1502 & 5407 & 5275 & 8755 & 8998 & 921 \\
\hline $\begin{array}{l}\text { Сумма НДФЛ удержанная, } \\
\text { млн руб. }\end{array}$ & 685 & 876 & 1056 & 1501 & 5275 & 5255 & 8727 & 8546 & 921 \\
\hline $\begin{array}{l}\text { Сумма НДФЛ } \\
\text { перечисленная, млн руб. }\end{array}$ & 649 & 828 & 1026 & 1418 & 4961 & 5151 & 8591 & 8430 & 918 \\
\hline $\begin{array}{l}\text { Сумма НДФЛ, излишне } \\
\text { удержанная налоговым } \\
\text { агентом, млн руб. }\end{array}$ & 6 & 5 & 16 & 19 & 22 & 16 & 34 & 10 & 0 \\
\hline $\begin{array}{l}\text { Сумма НДФЛ, } \\
\text { неудержанная налоговым } \\
\text { агентом, млн руб. }\end{array}$ & 25 & 14 & 15 & 17 & 163 & 15 & 47 & 448 & 1 \\
\hline
\end{tabular}

Источник. URL: https://www.nalog.ru/rn77/related_activities/statistics_and_analytics/forms/ 
Доходы физических лиц: вопросы налогообложения трансграничных операций...

ствует о сокращении за последние годы сумм НДФЛ и увеличении в 2018 г. в 10 раз суммы НДФЛ, не удержанной налоговым агентом (Альпидовская, Грязнова, 2020).

Данные анализа отражают результаты сотрудничества ФНС РФ и налоговых администраций различных стран. С 2018 г. ФНС впервые в автоматическом режиме стала получать информацию о зарубежных активах россиян (за 2017 г. в 58 юрисдикциях). Эти сведения позволили выявить 1015\% несоответствий с отчетностью налогоплательщиков.

Конвенция по взаимной административной помощи по налоговым делам, к которой Россия присоединилась в 2015 г., объединяет более 120 стран и позволяет осуществлять взаимодействие в виде обмена информацией, проведения совместных проверок, взыскания налоговой задолженности за рубежом и пр. ${ }^{24}$ C 2020 г. вступил в силу протокол об автоматическом обмене налоговой информацией по отдельным видам доходов и имущества физических и юридических лиц в государствах - участниках СНГ ${ }^{25}$. Реализация данных проектов способствует повышению налоговой определенности - сокращению теневой экономики, противодействию противозаконному сокрытию капиталов и уклонению от налогообложения (Синенко, Чунарева, 2018).

Несмотря на положительные тенденции, актуальность вопросов совершенствования налогообложения доходов физических лиц от трансграничных операций остается. Для решения проблемы отрицательного сальдо по трансграничным переводам физических лиц предлагается ввести налогообложение данных переводов ${ }^{26}$. Налоговыми агентами могут выступать коммерческие банки либо платежные системы, взымающие комиссию за осуществление дан-

24 Федеральный закон от 04.11.2014 г. № 325-Ф3 «О ратификации Конвенции о взаимной административной помощи по налоговым делам».

25 Распоряжение Правительства РФ от 30.10.2018 г. № 2349-р «О подписании Протокола об обмене информацией в электронном виде между государствами - участниками СНГ для осуществления налогового администрирования».

26 Предложения по дополнительным источникам налоговых доходов бюджетов бюджетной системы Российской Федерации. 2020. URL: http://council.gov.ru/media/files/ hJOUdfcMdnOOwdFKOUP1jyHIubbjFENd.pdf ных операций. Налоговая база может рассчитываться как сумма перечислений, а налоговые ставки (до $0,1 \%$ ) определяются дифференцированно в зависимости от страны, куда осуществляется перевод. Полагаем, что поступления от данного платежа превысят 603 млн руб. в квартал.

Трансграничные переводы физических лиц являются динамичным сегментом международного финансового рынка, при этом налогообложение данных операций имеет ряд проблем, решение которых требует внимания как на национальном, так и на международном уровне. Вопросы определения «непосредственного выгодоприобретателя» для определенных категорий доходов физических лиц, порядок взаимосогласительных процедур в рамках международных договоров РФ в сфере налогообложения и несправедливость обложения налогами доходов компаний из офшорных юрисдикций по ставкам ниже НДФЛ требуют совершенствования механизмов регулирования налоговых аспектов трансграничных операций. Россия в 2021 г. инициировала и договорилась с 34 странами о пересмотре соглашений об избежании двойного налогообложения с целью увеличения ставок по налогу на доходы физических лиц от дивидендов до 15\%, а на проценты - до 5\%. Таким образом, в целях противодействия размыванию налоговой базы и выводу прибыли из-под налогообложения (конвенция MLI) борьба с агрессивной оптимизацией налогообложения в мире будет продолжаться.

\section{СПИСОК ЛИТЕРАТУРЫ (REFERENCES)}

Альпидовская М.Л., Грязнова А.Г. (Ред.). 2020. Социально-экономическое развитие в эпоxy глобальных перемен. Т. 2. Москва-Тверь: Тверской государственный университет. 542 с. [Al'pidovskaya M.L., Gryaznova A.G. (Eds.). 2020. Socio-economic development in the era of global changes. Vol. 2. Moscow-Tver': Tverskoy gosudarstvennyy universitet. 542 p. (In Russ.)]

Князев А. 2019. Механизм ДИДН - защита от двойного налогообложения. Бухгалтерия $u$ банки. № 9. С. 30-33. [Knyazev A. 2019. Mechanism 
of agreements on avoidance of double. Bukhgalteriya i banki. No 9. PP. 30-33. (In Russ.)]

Синенко О.А. 2020. Трансформация налогообложения доходов физических лиц в условиях цифровизации экономики. Теоретическая экономика. № 8. С. 39-54. [Sinenko O.A. 2020. Transformation of taxation of personal income in the context of digitalization of the economy. Teoreticheskaya ekonomika. No 8. PP. 39-54. (In Russ.)]

Синенко О.А., Чунарева Е.В. 2018. Аналитический обзор практики обложения доходов физических лиц в зарубежных странах. Экономика и бизнес: теория и практика. № 11-2. С. 7479. [Sinenko O.A., Chunareva E.V. 2018. Analytical review of the practice of personal income taxation in foreign countries. Ekonomika $i$ biznes: teoriya $i$ praktika. No 11-2. PP. 74-79. (In Russ.)]

Хаванова И.А. 2016. Международнье договоры Российской Федерации об избежании двойного налогообложения. Москва: Юриспруденция. 352 с. [Khavanova I.A. 2016. International treaties of the Russian Federation on the avoidance of double taxation. Moscow: Yurisprudentsiya. 352 p. (In Russ.)]

Holmes K. 2007. International Tax Policy and Double Tax Treaties: An Introduction to Principles and Application. Amsterdam: IBFD. PP. 22-24.

Jogarajan S. 2012. The Conclusion and Termination of the «First» Double Taxation Treaty. British Tax Review. Vol. 3. P. 283-306.

\title{
PERSONAL INCOME: TAXATION ISSUES OF CROSS- BORDER TRANSACTIONS IN THE RUSSIAN FEDERATION
}

\section{Olga Sinenko ${ }^{1}$}

\author{
Author affiliation: ${ }^{1}$ Far Eastern Federal University (Russia, Vladivostok). \\ Corresponding author: Olga Sinenko (sinenko.oa@dvfu.ru).
}

\begin{abstract}
The article studies the taxation of cross-border transactions of individuals in Russia. Approaches to apply the concept of person with an actual right to income are considered. The features of international treaties of the Russian Federation in the field of taxation are highlighted. Methods to eliminate double taxation are settled. The study of personal income tax is carried out under tax rates stated in double taxation treaties between 2011 and 2019. The features of personal income tax for certain categories, regulated by international double taxation treaties of the Russian Federation, are fetched out; the procedure for the mutual agreement procedure for resolving disputes on taxation issues is considered.
\end{abstract}

KEYWORDS: personal income tax, cross-border transactions, double taxation treaties, actual recipient of income, elimination of double taxation.

JEL-code: H20, H26, H30.

DOI: $10.46782 / 1818-4510-2021-2-94-106$

Received 6.05.2021 